\title{
A conserved C-terminal peptide of sorghum phosphoenolpyruvate carboxylase promotes its proteolysis, which is prevented by Glc-6P or the phosphorylation state of the enzyme
}

\author{
Jacinto Gandullo ${ }^{1}$ Rosario Álvarez ${ }^{1} \cdot$ Ana-Belén Feria $^{1} \cdot$ José-Antonio Monreal $^{1} \cdot$ Isabel Díaz $^{2} \cdot$ Jean Vidal $^{3}$. \\ Cristina Echevarría ${ }^{1}$ (D)
}

Received: 7 May 2021 / Accepted: 28 July 2021

(c) The Author(s) 2021

\begin{abstract}
Main conclusion A synthetic peptide from the $\mathrm{C}$-terminal end of $\mathrm{C}_{\mathbf{4}}$-phosphoenolpyruvate carboxylase is implicated in the proteolysis of the enzyme, and Glc-6P or phosphorylation of the enzyme modulate this effect.
\end{abstract}

Abstract Phosphoenolpyruvate carboxylase (PEPC) is a cytosolic, homotetrameric enzyme that performs a variety of func-
tions in plants. Among them, it is primarily responsible for $\mathrm{CO}_{2}$ fixation in the $\mathrm{C}_{4}$ photosynthesis pathway $\left(\mathrm{C}_{4}\right.$-PEPC). Here
we show that proteolysis of $\mathrm{C}_{4}$-PEPC by cathepsin proteases present in a semi-purified PEPC fraction was enhanced by the
presence of a synthetic peptide containing the last 19 amino acids from the C-terminal end of the PEPC subunit (pC19).
Threonine (Thr) 944 and Thr948 in the peptide are important requirements for the pC19 effect. $\mathrm{C}_{4}$-PEPC proteolysis in the
presence of pC19 was prevented by the PEPC allosteric effector glucose 6-phosphate $(\mathrm{Glc}-6 \mathrm{P})$ and by phosphorylation of the
enzyme. The role of these elements in the regulation of PEPC proteolysis is discussed in relation to the physiological context.

Keywords $\mathrm{C}_{4}$ photosynthesis $\cdot \mathrm{C} 19$ peptide $\cdot \mathrm{C}$-terminus $\cdot$ Proteolysis regulation $\cdot$ Sorghum leaves

\begin{tabular}{|c|c|}
\hline \multicolumn{2}{|c|}{ Abbreviations } \\
\hline C-term & $\begin{array}{l}\text { C-terminal } 19 \text { amino acids of sorghum } \\
\mathrm{C}_{4} \text {-PEPC }\end{array}$ \\
\hline pC19 & $\begin{array}{l}\text { Conserved } 19 \text { amino acid synthetic pep- } \\
\text { tide from the carboxy terminus of sorghum } \\
\mathrm{C}_{4} \text {-PEPC }\end{array}$ \\
\hline Glc-6P & Glucose 6-phosphate \\
\hline PA & Phosphatidic acid \\
\hline PEP & Phosphoenolpyruvate \\
\hline
\end{tabular}

Communicated by Dorothea Bartels.

Cristina Echevarría

echeva@us.es

1 Departamento de Biología Vegetal, Facultad de Biología, Universidad de Sevilla, Avenida Reina Mercedes nº 6, 41012 Seville, Spain

2 Centro de Biotecnología y Genómica de Plantas, Universidad Politécnica de Madrid, Campus de Montegancedo, Autovía M40 (km 38), Pozuelo de Alarcón, 28034 Madrid, Spain

3 Institut de Biotechnologie des Plantes, UMR8618, Bâtiment 630, Université de Paris-Sud 11, 91405 Orsay, Cedex, France
PEPC Phosphoenolpyruvate carboxylase

sp-PEPC Semi-purified PEPC fraction with protease activity

\section{Introduction}

Phosphoenolpyruvate carboxylase (PEPC; EC 4.1.1.31) catalyzes the addition of bicarbonate to phosphoenolpyruvate (PEP) to form oxaloacetate, which is reduced to malate by the enzyme malate dehydrogenase (MDH). The family of plant-type PEPCs (PTPCs) in sorghum includes four $\mathrm{C}_{3}$-type PEPCs and the photosynthetic $\mathrm{C}_{4}$-PEPC (Paterson et al. 2009). $C_{4}$-PEPC catalyzes the first carboxylation step in $\mathrm{C}_{4}$ photosynthesis, and gene expression is activated during the greening of the $\mathrm{C}_{4}$ leaf when PEPC accumulates in the cytosol of mesophyll cells as required for the functioning of the $C_{4}$ pathway (Chollet et al. 1996). $C_{4}$-PEPC has been further studied in relation to its catalytic and regulatory properties and the biochemical and signaling mechanisms that control its subcellular activity (Chollet et al. 1996; Echevarría and Vidal 2003; Izui et al. 2004). $C_{3}$-PEPCs are also key enzymes in the metabolism of carbon and nitrogen, 
with central roles in respiration, amino acid synthesis, and the development and germination of seeds (Chollet et al. 1996; O'Leary et al. 2011). All PTPCs have a conserved $\mathrm{N}$-terminal seryl residue that is phosphorylated by PEPC kinases (PEPCks; Echevarría and Vidal 2003), whereas this residue is absent from bacterial-type PEPC (BTPC; Sánchez and Cejudo 2003). Phosphorylation involves an N-terminal regulatory serine (Ser8 in $\mathrm{C}_{4}$-PEPC from sorghum), and this regulatory post-translational modification (PTM) interacts with metabolite effectors to decrease its sensitivity to feedback inhibition by L-malate and increase its affinity for the allosteric activator Glc-6P and its Vmax (Echevarría and Vidal 2003; Nimmo 2003). PEPC is also subjected to different PTMs, such as monoubiquitination (Uhrig et al. 2008; Ruíz-Ballesta et al. 2014, 2016), nitric oxide-related PTMs (S-nitrosylation, Tyr-nitration), and PTMs associated with oxidative stress (carbonylation; Arias-Baldrich et al. 2017; Baena et al. 2017). Monoubiquitination of Arabidopsis $\mathrm{C}_{3}$-PEPC is selectively degraded by autophagy (Baena et al. 2021). However, it is not known whether $\mathrm{C}_{4}$-PEPC is modified by monoubiquitination, and evidence of a possible degradation mechanism controlling the amount of $\mathrm{C}_{4}$-PEPC in the cytosol of mesophyll cells is lacking.

The C-terminal 19 amino acid domain (hereafter, "C-term") is highly conserved in all PTPCs sequenced thus far and is also conserved in prokaryotic PEPCs (Lepiniec et al. 1993; Chollet et al. 1996; Gehrig et al. 1998). It has been implicated in the stability of the protein (Grisvard et al. 1998; Dong et al. 1999), the maintenance of catalytic activity, and the oligomeric state of the enzyme (Dong et al. 1999). Limited 3' deletion in the Ppc gene from Escherichia coli resulted in a decreased amount of the enzyme and suppression of its catalytic activity (Sabe et al. 1984). Studies of the recombinant $\mathrm{C}$-terminal truncated $\mathrm{C}_{4}$-PEPC concluded that the conserved C-terminal QNTG tetrapeptide of sorghum $\mathrm{C}_{4}$ - $\mathrm{PEPC}$ is indispensable for maximal catalytic activity but not for homotetramer formation (Dong et al. 1999). Crystallographic studies have deciphered the three-dimensional structure of the E. coli and maize $\left(\mathrm{C}_{4}\right)$ PEPCs, making clear the contribution of the enzyme $\mathrm{C}$-terminal end to active and inhibitor sites (Kai et al. 1999; Matsumura et al. 2002).

The C-term is embedded in a hydrophobic region of the protein subunit (Matsumura et al. 2002), and in sorghum the $\mathrm{C}_{4}$-PEPC enzyme can be found in vitro in two different conformational states that differ in the accessibility of their C-terminal tail to specifically designed antibodies (Álvarez et al. 2003). We have also previously reported that a synthetic peptide containing the last 19 amino acids of the C-term of $\mathrm{C}_{4}$-PEPC sorghum leaves (pC19) specifically inhibits the in vitro phosphorylation of enzymes by PEPCk (Álvarez et al. 2003).

Protein purification from dark-adapted sorghum leaves on hydroxyapatite and anion exchange on mono Q led to fractions highly enriched in $\mathrm{C}_{4}$-PEPC (sp-PEPC). Among the contaminating proteins in these fractions we have been able to detect the presence of cathepsin proteases, mainly of the B and L types (Gandullo et al. 2019; Plaxton 2019). We have also shown that PEPC proteolysis by these cathepsin proteases is highly increased by the presence of the anionic phospholipids phosphatidic acid (PA), phosphatidylinositol (PI), and lyso-phosphatidic acid (LPA), which in turn inactivates the enzyme by means of a conformational change clearly detected by the exposing of the C-term usually embedded in the native, active enzyme. Conversely, the allosteric activator Glc-6P returns the exposed C-term of PEPC to the embedded conformation (Gandullo et al. 2019), increasing the stability of the protein. These changes in the conformational state of the enzyme seem to be essential to its stability, as the exposed C-term conformation is highly sensitive to proteolysis by cathepsin proteases that co-purify with PEPC.

The fact that this sequence is highly conserved, and that it is modulated by regulators such as anionic phospholipids or Glc-6P (Gandullo et al. 2019), suggests a possible role for $\mathrm{C}$-term in modulating PEPC activity, stability, or the aggregation state of the enzyme. Whether the mechanism based on the C-term PEPC has physiological significance in the $\mathrm{C}_{4}$ leaf is an open question in our group. Here we report that the addition of a synthetic C-term (19 amino acid) peptide to the semi-purified PEPC fraction (sp-PEPC) results in a rapid decrease in enzyme activity due to cathepsin-based degradation. This is modulated by the antagonistic effect of the activator Glc-6P and the extent of phosphorylation (Ser8 of the opposite N-terminal) of the enzyme subunit. A possible implication of these findings for the physiological mechanism that regulates PEPC degradation/amount in the cytosol of mesophyll cells is discussed.

\section{Materials and methods}

\section{Materials}

The peptides C19 ([Y]942EDTLILTMKGIAAGMQNTG960), C15 (C19 lacking the QNTG motif), Thr/Tyr-mutated C19 ([Y]942EDY ${ }_{944}$ LILY $_{948}$ MKGIAAGMQNY $_{959}$ G960), N-terminal dephosphorylated peptide N-t-OH (1-MASERHHSIDAQLRALAP-18), and N-terminal phosphorylated peptide $\mathrm{N}$-t-OP (1-MASERHHS $\left[\mathrm{PO}_{3} \mathrm{H}_{2}\right]$ IDAQLRALAP-18) were used in this study. The peptides LI (108LAHRRRNSKLKHGDFSDEGS127), L2 (333AEEVQSTPASKKVTKYYIEFWKQIPPNE360), and L3 (907SFKVTPQPPLSKEFADENKPAGLVKLN933), correspond to additional loops present in the computerized model of the sorghum $\mathrm{C}_{4}$-PEPC compared to the three-dimensional structure of E. coli PEPC. Peptides $\mathrm{L} 2$ and L3 were as hydrophobic as peptide C19. The L1, L2, 
and L3 peptides were supplied by PolyPeptide Group (Strasbourg, France). C19, C15, L1, L2, and L3 have been described previously (Álvarez et al. 2003). Specific polyclonal antibodies against the $\mathrm{N}$-terminal peptide (N-t-IgGs) were raised against the N-t-OH peptide of sorghum $\mathrm{C}_{4}$-PEPC containing the phosphorylation motif (Pacquit et al. 1995). PEPC antibodies against $\mathrm{C}_{4}$-PEPC from sorghum leaves were prepared by the General Services of Research from Seville University. N-tIgGs were supplied by PolyPeptide Group.

\section{Plant growth conditions}

Sorghum plants (Sorghum bicolor [L.] Moench, var. PR87G57; Pioneer Hi-Bred, Madrid, Spain) were grown under controlled environmental conditions in a greenhouse under a $12 \mathrm{~h}$ photoperiod $\left(350 \mu \mathrm{mol} \mathrm{m} \mathrm{m}^{-2} \mathrm{~s}^{-1}\right.$, photosynthetically active radiation), a temperature of $28 / 20{ }^{\circ} \mathrm{C}$ (light/ dark), and $60 \%$ relative humidity in hydroponic cultures with nitrate-type nutrient solution (Hewit 1966).

\section{Preparation of the semi-purified $\mathrm{C}_{4}$-PEPC fraction}

All procedures were performed at $4{ }^{\circ} \mathrm{C}$. Dark-adapted $(12 \mathrm{~h})$ sorghum leaves $(20 \mathrm{~g})$ were homogenized in a Waring blender with $100 \mathrm{~mL}$ extraction buffer containing $100 \mathrm{mM}$ Tris- $\mathrm{HCl} \mathrm{pH}$ 7.5, 5\% (v/v) glycerol, $1 \mathrm{mM}$ EDTA, $10 \mathrm{mM}$ $\mathrm{MgCl}_{2}, 14 \mathrm{mM} \beta$-mercaptoethanol, $1 \mathrm{mM}$ phenylmethylsulfonyl fluoride (PMSF), $10 \mu \mathrm{g} \mathrm{mL}^{-1}$ chymostatin, $10 \mu \mathrm{g} \mathrm{mL}^{-1}$ leupeptin, $10 \mathrm{mM}$ potassium fluoride, and $2 \%(\mathrm{w} / \mathrm{v})$ polyvinylpyrrolidone (PVP). The homogenate was filtered through two layers of 80- $\mu \mathrm{m}$ nylon net and centrifuged at 45,000 g for $10 \mathrm{~min}$. Proteins in the supernatant were precipitated by polyethylene glycol 8000 (PEG; 8.5-15\%), then sedimented by centrifugation $(45,000 \mathrm{~g}, 10 \mathrm{~min})$. The pellet was dissolved in $7 \mathrm{~mL}$ buffer A containing $50 \mathrm{mM}$ Hepes/KOH pH 7.1, $5 \mathrm{mM} \mathrm{MgCl} 2,1 \mathrm{mM}$ EDTA, and $5 \mathrm{mM}$ dithiothreitol (DTT). Hydroxyapatite ( $5 \mathrm{~mL}$; Econo-Pac CHT-II, Bio-Rad, equilibrated with buffer A and Mono Q [5 mL]; catalog no. 723-4122, Bio-Rad Laboratories) chromatography was performed according to the procedure of McNaughton et al. (1989), except that the chromatography was done in a BioRad Econo-System at low pressure. The final specific activity for sp-PEPC was $78.5 \pm 5 \mathrm{U} \mathrm{mg} \mathrm{prot}^{-1}$.

\section{Preparation of standard crude extract from leaves}

The protein extracts used in Fig. 6 were obtained by grinding $0.2 \mathrm{~g}$ fresh weight (FW) leaf tissue using sand and $1 \mathrm{~mL}$ extraction buffer containing $100 \mathrm{mM}$ Tris- $\mathrm{HCl} \mathrm{pH}$ 7.5, 20\% (v/v) glycerol, $1 \mathrm{mM}$ EDTA, $10 \mathrm{mM} \mathrm{MgCl}{ }_{2}$, $14 \mathrm{mM} \beta$-mercaptoethanol, $1 \mathrm{mM}$ PMSF, and $10 \mu \mathrm{g} \mathrm{mL}$ leupeptin. The homogenate was centrifuged at $12,000 \mathrm{~g}$ for $2 \mathrm{~min}$ to disrupt the mesophyll and bundle-sheath cells.
The crude extract typically contained $6 \mathrm{U}$ PEPC/mg protein. When indicated, sorghum leaves were illuminated at $700 \mu \mathrm{mol} \mathrm{m}{ }^{-2} \mathrm{~s}^{-1}$ for $2 \mathrm{~h}$ before protein extraction.

\section{Proteolytic assay: standard and incubation with different peptides and metabolites}

In most experiments, an aliquot of sp-PEPC (0.3 U) containing proteases, mainly cathepsin B and L (Gandullo et al. 2019), was incubated at $30^{\circ} \mathrm{C}$ for $3 \mathrm{~h}$ with and without various synthetic peptides (C19, C15, Thr/Tyr-mutated C19, L1, L2, and L3) and metabolites (Glc-6P, PEP, or L-malate) in $50 \mu \mathrm{L}$ of a medium containing $100 \mathrm{mM}$ Tris-HCl pH 8, 20\% glycerol, 5 mM MgCl 2,1 mM EDTA, $1 \mathrm{mM}$ PMSF, and $10 \mu \mathrm{g} / \mathrm{mL}$ leupeptin. At the indicated time, aliquots $(5 \mu \mathrm{L})$ were taken to measure PEPC activity at $\mathrm{pH} 8.0$ and $2.5 \mathrm{mM}$ PEP. Activity was expressed as a percentage of the initial activity. At the end of the incubation period, samples were analyzed by SDS-PAGE (10\% [w/v] acrylamide) or native PAGE (7\% [w/v] acrylamide) according to Laemmli (1970). All gels were stained with Coomassie Blue.

\section{Proteolytic assay using substrates containing AMC fluorophore}

Hydrolysis of commercial substrates containing AMC (7-amino-4-methyl coumarin) fluorophore was performed after digestion of PEPC present in the sp-PEPC fraction overnight at $30{ }^{\circ} \mathrm{C}$ in the presence of pC19 $(60 \mathrm{nmol})$. After this, commercial substrates were added. The proteolytic assay was performed on microplates. The optimal $\mathrm{pH}$ for each type of protease was used. The standard assay volume was $100 \mu \mathrm{L}$ containing $25 \mu \mathrm{L}$ sp-PEPC, and the corresponding substrate was added to a final concentration of $0.2 \mathrm{mM}$ (Carrillo et al. 2011). Cathepsin B-like (Cat-B) and L-like (Cat-L) activity was assayed with Z-RR-AMC (N-carbobenzoxyloxy-Arg-Arg-7-amido-4-methylcoumarin) or Z-FR-AMC (N-carbobenzoxyloxy-Phe-Arg7-amido-4-methylcoumarin) substrates, respectively, and a buffer containing $0.1 \mathrm{M}$ citrate $\mathrm{pH} 6,0.15 \mathrm{M} \mathrm{NaCl}$, and $5 \mathrm{mM} \mathrm{MgCl}_{2}$ (Carrillo et al. 2011). The mixture was incubated at $37^{\circ} \mathrm{C}$ for $24 \mathrm{~h}$, and the emitted fluorescence was measured with a $365 \mathrm{~nm}$ excitation wavelength filter and a $465 \mathrm{~nm}$ emission wavelength filter. Blanks were used to account for the spontaneous breakdown of substrates, and results were expressed as $\mu \mathrm{mol} \mathrm{min}^{-1} \mathrm{~mL}^{-1}$. The system was calibrated with a known amount of AMC in a standard reaction mixture. 


\section{Assay of PEPC activity}

PEPC activity was measured spectrophotometrically at an optimal $\mathrm{pH}$ of 8.0 using the NAD-dependent malate dehydrogenase (NAD-MDH)-coupled assay at $2.5 \mathrm{mM}$ PEP (Echevarría et al. 1994). Assays were initiated with the addition of an aliquot of the enzyme preparation or crude extract. A unit of enzyme was defined as the amount of PEPC that catalyzed the carboxylation of $1 \mu \mathrm{mol}$ PEP $\min ^{-1}$ at $\mathrm{pH} 8$ and $30^{\circ} \mathrm{C}$.

\section{In vitro phosphorylation with PKA and PEPC phosphorylation state}

Aliquots of sp-PEPC (0.1 U PEPC) were phosphorylated in vitro at $\mathrm{pH} 8$ using the catalytic subunit of cAMP-dependent protein kinase (PKA) from bovine heart (5 U) according to Echevarría et al. (1994). The phosphorylation state of PEPC was determined via the malate test (malate inhibition at a suboptimal $\mathrm{pH}$ of 7.3) and expressed as the $\mathrm{IC}_{50}$. A high $\mathrm{IC}_{50}$ is correlated with a high degree of PEPC phosphorylation (Echevarría et al. 1994).

\section{Electrophoresis and Western blotting}

The samples were subjected to SDS-PAGE $(10 \%$ [w/v] acrylamide) according to Laemmli's (1970) method for $2 \mathrm{~h}$ at $100 \mathrm{~V}$ and room temperature in a Mini-Protean ${ }^{\circledR}$ III-2D cell (Bio-Rad). For native PAGE, the samples were immediately mixed with sample buffer (Tris-HCl $100 \mathrm{mM}, 20 \%$ [v/v] glycerol, and $0.05 \%$ [w/v] bromophenol blue) and analyzed by PAGE $(7 \%[\mathrm{w} / \mathrm{v}]$ acrylamide). The final concentrations in the separation gel were as follows: Tris-HCL $375 \mathrm{mM} \mathrm{pH}$ 8.8 , APS $(0.5 \%[\mathrm{w} / \mathrm{v}])$, and $6 \mathrm{mM}$ TEMED. The stacking gel (4\% [w/v] acrylamide) contained $125 \mathrm{mM}$ Tris- $\mathrm{HCl}, \mathrm{pH} 6.8$, and was polymerized like the separating gel. The electrode buffer (pH 8.3) contained $0.025 \mathrm{M}$ Tris- $\mathrm{HCl}$ and $0.192 \mathrm{M}$ glycine. Electrophoresis was performed at $100 \mathrm{~V}$ for $3 \mathrm{~h}$ and at $4{ }^{\circ} \mathrm{C}$ with a Mini-Protean ${ }^{\circledR}$ III-2D cell. After electrophoresis, proteins on the gels were stained with Coomassie Blue R-250 or electro-blotted onto a nitrocellulose membrane (N-8017; Sigma) at $10 \mathrm{~V}\left(5.5 \mathrm{~mA} \mathrm{~cm}^{-2}\right)$ for $30 \mathrm{~min}$ in a semi-dry transfer blotting apparatus (Bio-Rad). Membranes were blocked in Tris-buffered saline $(20 \mathrm{~mm}$ Tris- $\mathrm{HCl}$ and $0.15 \mathrm{mM} \mathrm{NaCl} \mathrm{pH} \mathrm{7.5)} \mathrm{containing} 5 \%$ (w/v) powdered milk. PEPC bands were immunochemically labeled by overnight incubation of the membranes at room temperature in $20 \mathrm{~mL}$ Tris-buffered saline containing $40 \mu \mathrm{g}$ PEPC-IgGs (antibodies against $\mathrm{C}_{4}$-PEPC from sorghum leaves). Subsequent detection was performed with affinity-purified goat anti-rabbit IgGs and a chemiluminescence detection system (Super Signal West Dura Signal, Pierce) according to the manufacturer's instructions. Native $\mathrm{C}_{4}$-PEPC has been described as a tetrameric enzyme with a molecular weight of $440 \mathrm{kDa}$ (Chollet et al. 1996).

\section{Separation of $C_{4}-P E P C$ and $C 19$ protease by native PAGE}

All steps were performed at $4{ }^{\circ} \mathrm{C}$. sp-PEPC (50 U) was analyzed by native PAGE (7\% [w/v] acrylamide) as described above but in the absence of the stacking gel. After electrophoresis, we located the PEPC band by incubating the gel for $5 \mathrm{~min}$ in a medium containing the assay components of PEPC activity and $0.16 \mathrm{mM} \mathrm{CaCl}_{2}$. Pi released by the PEPC reaction precipitated as a white calcium phosphate $\left(\mathrm{Ca}_{3}\left[\mathrm{PO}_{4}\right]_{2}\right)$ band. The PEPC band was excised from the gel and the proteins electro-eluted for $12 \mathrm{~h}$ at $5 \mathrm{~V}$ (model 422 electro-eluter; Bio-Rad). The electro-eluted fraction was recovered $(400 \mu \mathrm{L} / 1.3 \mathrm{mg}$ protein) in Tris-Gly buffer ( $25 \mathrm{mM}$ Tris- $\mathrm{HCl}$ and $192 \mathrm{mM}$ Gly $\mathrm{pH}$ 8.3) and concentrated to a volume of $100 \mu \mathrm{L}$ by centrifugation at $8,000 \mathrm{~g}$ for $20 \mathrm{~min}$ at $4{ }^{\circ} \mathrm{C}$ with a Millipore filter (100,000 Da). This highly purified fraction containing PEPC, in which proteolytic activity was absent, was named "electro-eluted PEPC" (Fig. 2b, lane 4).

\section{Protein quantification}

We determined total protein amounts with Bradford's (1976) method using bovine serum albumin (BSA) as the standard.

\section{Statistics}

All data in this report were obtained from at least three independent experiments. Values are means $\pm \mathrm{SD}(n \geq 3)$.

\section{Results}

\section{Proteolysis of $\mathrm{C}_{4}-\mathrm{PEPC}$ from sorghum leaves in the presence of $\mathrm{pC} 19$}

A marked decrease in PEPC activity was observed when sp-PEPC was incubated $\left(2-4 \mathrm{~h}\right.$ at $\left.30^{\circ} \mathrm{C}\right)$ in the presence of a synthetic, hydrophobic peptide that mimics the sequence of the last 19 amino acids at the C-terminal end of the enzyme pC19 (Fig. 1, + C19).

SDS-PAGE analysis of the sp-PEPC fraction after incubation with $\mathrm{pC} 19$ revealed that the decrease in PEPC activity was due to a loss of the corresponding protein (Fig. 1b, lane 3), whereas the enzyme remained stable in the control (Fig. 1b, lane 1). We checked that this decrease was not due to insolubilization of the enzyme following incubation (Fig. 1b, lanes 2 and 4). Immunoblots of aliquots incubated at low concentrations of $\mathrm{pC} 19$ indicated that PEPC was 
a
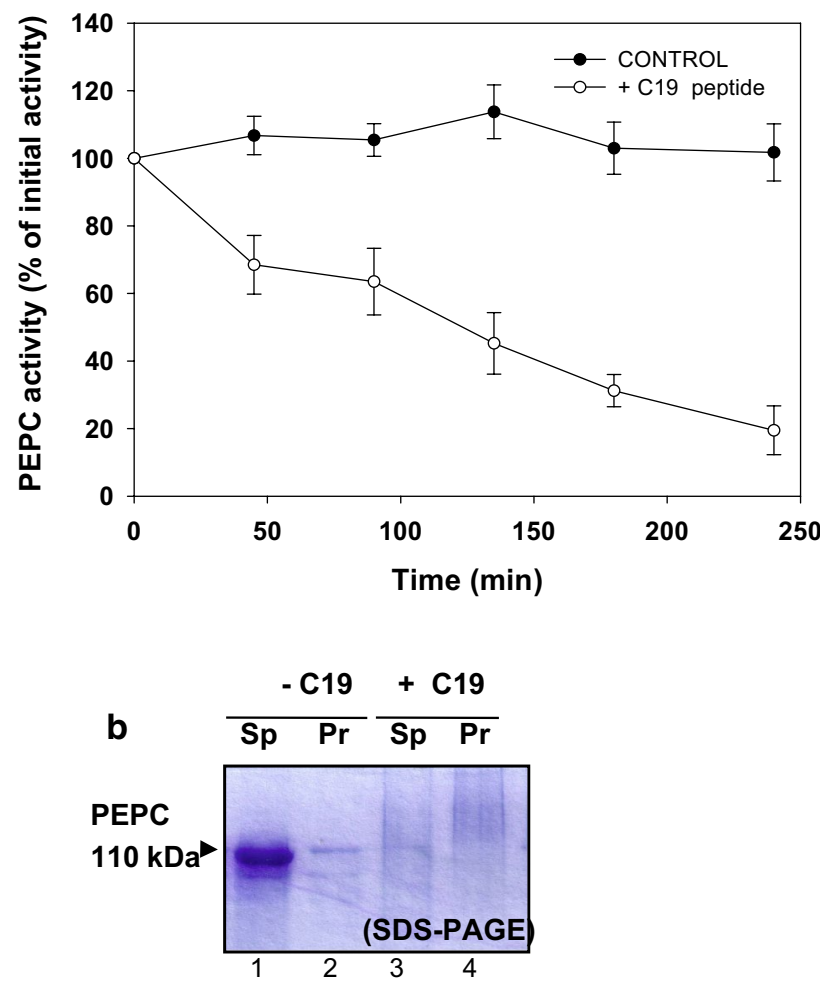

C

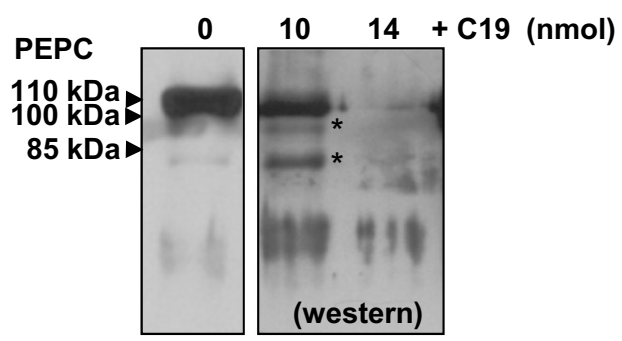

Fig. 1 Effect of pC19 on PEPC activity/amount. PEPC protease activity was followed in $50 \mu \mathrm{L}$ of incubation medium containing 0.3 $\mathrm{U}$ sp-PEPC, $\pm 60 \mathrm{nmol}$ of pC19 at $30{ }^{\circ} \mathrm{C}$. a Time course of PEPC activity during the incubation assay $(5 \mu \mathrm{L}$ aliquot, $\mathrm{pH} 8$ and $2.5 \mathrm{mM}$ of PEP) in the absence or presence of $\mathrm{pC} 19$ (100\% corresponding to $0.3 \mathrm{U}$ PEPC and value represent the mean $\pm \mathrm{SD}$ of three independent experiments). b SDS-PAGE analysis of PEPC amounts: after $3 \mathrm{~h}$ of incubation, samples were centrifuged $(12.000 \mathrm{~g}, 10 \mathrm{~min})$ and supernatant (Sp) and precipitate (Pr) were analyzed by SDS-PAGE and proteins were stained with Coomassie blue. $\mathbf{c}$ Pattern of proteolysis of PEPC by proteases in sp-PEPC in the presence of low amount of pC19. Sp-PEPC $(0.01 \mathrm{U})$ was incubated $1 \mathrm{~h}$, at $30^{\circ} \mathrm{C}$ in the absence (PEPC) or presence of 10 or $14 \mathrm{nmol}$ of $\mathrm{pC} 19(+\mathrm{C} 19)$. The samples were rapidly denatured to minimize proteolysis and analyzed by SDS-PAGE (10\% of acrylamide) and immunoblotting with PEPCIgGs

completely degraded after $3 \mathrm{~h}$ of incubation at $30^{\circ} \mathrm{C}$ in the presence of $14 \mathrm{nmol} \mathrm{pC19}$ (Fig. 1c). Incubation with a lower amount of peptide $(10 \mathrm{nmol})$ resulted in the accumulation of PEPC fragments. These fragments were approximately 100 and $85 \mathrm{kDa}$ (Fig. 1c, *). These results led us to believe

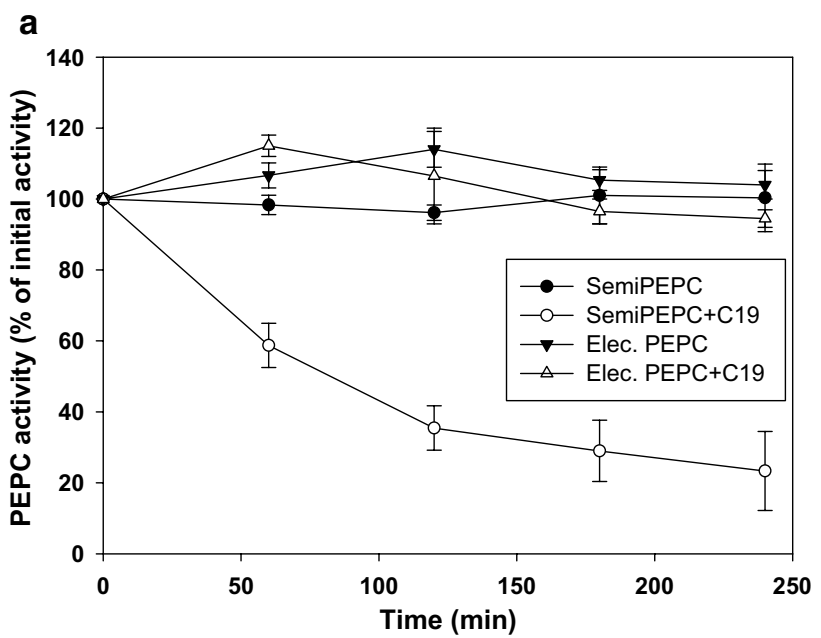

b

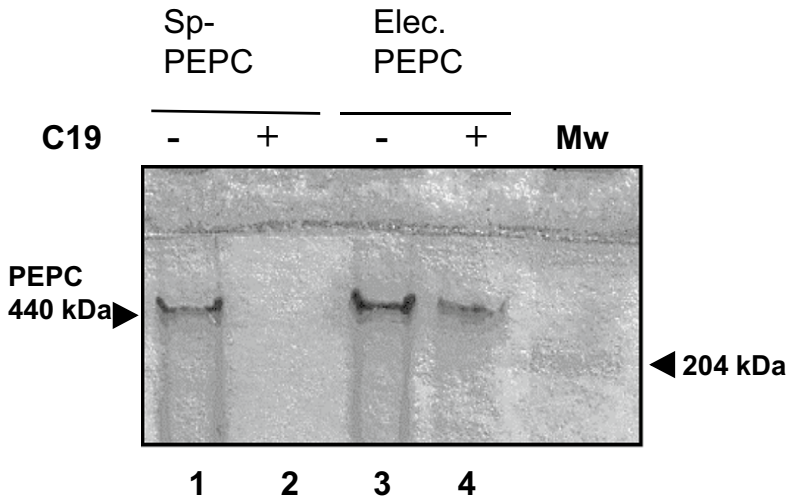

Fig. 2 Native-PAGE separates PEPC from the protease and electroeluted PEPC was not proteolysed in the presence of $\mathrm{pC} 19$. The spPEPC fraction was subjected to native PAGE and the PEPC protein band was electro-eluted. Aliquots containing 0.6 U of sp-PEPC or electro-eluted PEPC (Elec. PEPC) were incubated for $4 \mathrm{~h}, \pm 60 \mathrm{nmol}$ of pC19 (C19) in $50 \mu \mathrm{L}$ of assay medium. a PEPC activity expressed as the percentage of the initial activity. Values represent the mean \pm SD of 3 independent experiments). b Analysis by nativePAGE. MW, molecular weight markers

that the loss of PEPC activity was due to the proteolysis of PEPC in the presence of $\mathrm{pC} 19$. To confirm this, we subjected sp-PEPC to an additional purification step in native PAGE (7\% acrylamide) to obtain pure PEPC without proteolytic activity. First PEPC was localized with an in-gel activity assay, then the corresponding region was cut out and the PEPC recovered by electro-elution. In this case, incubation of the electro-eluted, highly purified PEPC with pC19 did not affect the enzyme activity (Fig. 2a) or the integrity of the protein (Fig. 2b, lane 4). This indicated that the proteases in sp-PEPC had indeed been separated from PEPC on native PAGE. In addition, the results confirmed that the loss of PEPC activity in the presence of $\mathrm{pC} 19$ was due to a proteolytic process. It is important to point out that in the 
absence of proteolytic activity, pC19 did not affect PEPC activity (Fig. 2a). Moreover, no higher molecular complexes were observed in the presence of the aforementioned peptide (Fig. 2b).

Previous results by our group had demonstrated that the main proteolytic activity present in sp-PEPC was cathepsin $\mathrm{B}$ and $\mathrm{L}$ from the cysteine protease superfamily (Gandullo et al. 2019). Cathepsin proteases are specifically inhibited by cystatins (Yamada et al. 2000; Martínez and Díaz 2008). To determine whether cathepsin proteases were responsible for the in vitro degradation of PEPC in the presence of pC19, we performed a proteolytic assay of PEPC in the presence and absence of the cystatins HvCPI2 and HvCPI6. As shown in Fig. 3, PEPC was partially degraded after 90 min of incubation with pC19 (lane 2), whereas proteolysis decreased in the presence of HvCPI2 and HvCPI6 (lanes 4 and 6).

We also assayed proteolytic activity with the commercial fluorescent substrates Z-RR-AMC and Z-FR-AMC for Cat-B and Cat-L proteases, respectively, to determine whether the effect of pC19 was on the protease activity or on PEPC. Figure $3 \mathrm{~b}$ shows the degradation of these fluorescent substrates regardless of the presence of $\mathrm{pC} 19$. This proves that PEPC is the target of $\mathrm{pC} 19$.

\section{Thr present in pC19 is an important requirement for PC19-PEPC interaction}

The C-terminal QNTG domain is indispensable for maximal catalytic activity but not for the homotetramer formation of sorghum $\mathrm{C}_{4}$-PEPC (Dong et al. 1999). To determine whether this conserved domain is essential to promote PEPC proteolysis, we assayed a truncated $\mathrm{pC} 19$ lacking the last four amino acids QNTG (pC15) and found it to be as effective as $\mathrm{pC} 19$ at triggering PEPC proteolysis (Fig. 4, + C15). Other synthetic peptides-L1 and the hydrophobic peptides L2 and L3, designed from computer-based modeling of the sorghum $\mathrm{C}_{4}$-PEPC (Kai et al. 1999; Matsumura et al. 2002), corresponding to solvent-exposed protein loops were tested but all failed to promote proteolysis of the enzyme (Fig. 4, L1, L2, L3). These data suggest that hydrophobicity alone cannot account for the positive effect of pC19 on PEPC proteolysis. This view is well supported by the fact that a mutated $\mathrm{pC} 19$ with an increased hydrophobic index (Thr944, Thr948, and Thr959 replaced by Tyr residues [(Y)942EDY 944 LILY $_{\mathbf{9 4 8}}$ MKGIAA GMQNY $\mathbf{9 5 9}$ G960]) lost its ability to promote PEPC proteolysis (Fig. 4, +C19 mut). Thus, our data suggest that $\mathrm{pC} 19$ is specifically required to enhance PEPC proteolysis and that Thr944 and Thr948 are important requirements for this interaction. Thus, direct interaction between the C-term of a PEPC with another native PEPC subunit could take place. The feasibility of this mechanism in vivo remains to be investigated. In the meantime, we have used pC19 as a tool to promote the proteolysis

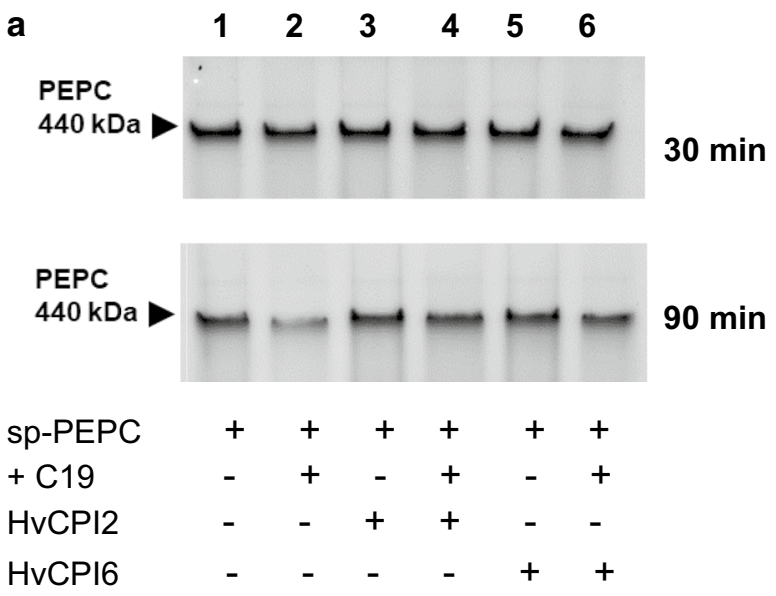

b

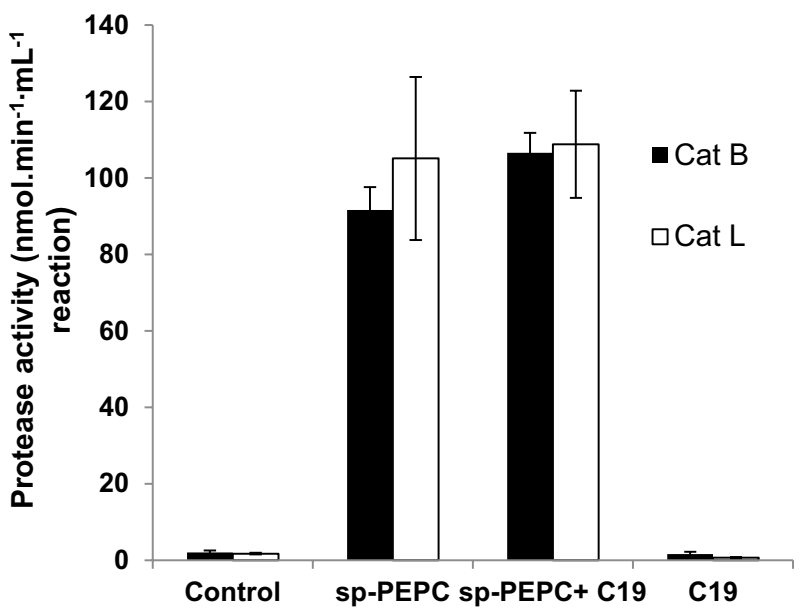

Fig. 3 Cystatin inhibits the protease activity in sp-PEPC in the presence of pC19. a An aliquot of $0.2 \mathrm{U}$ of sp-PEPC was incubated alone or in the presence of $\mathrm{pC} 19(+\mathrm{C} 19 ; 60 \mathrm{nmol})$ and $1 \mu \mathrm{M}$ of recombinant purified barley cystatins, Hordeum vulgate cystatin protein $\mathrm{HvCPI} 2$ and HvCPI6, in a final volume of $50 \mu \mathrm{L}$ containing $100 \mathrm{mM}$ of citrate buffer at $\mathrm{pH}$ 6. The incubation was carried at $37^{\circ} \mathrm{C}$ for 30 or $90 \mathrm{~min}$. Finally, samples were subjected to native PAGE $(7 \%$ acrylamide) and stained with Coomassie Blue. The bands intensity was quantified using the software PCBAS 2.0 and expressed as \% respect to the control. $\mathbf{b}$ The protease activity present in sp-PEPC is independent of the presence of pC19 $(+\mathrm{C} 19)$. Cathepsin B-like (CatB) and L-like (Cat-L) protease activities were assayed as described in Materials and methods using Z-RR-AMC and Z-FR-AMC specific fluorescent substrates respectively, and a citrate buffer, $\mathrm{pH}$ 6. The reaction was incubated at $37{ }^{\circ} \mathrm{C}$ for $24 \mathrm{~h}$. The system was calibrated with known amount of AMC in a standard reaction mixture. Control, used to account the spontaneous breakdown of substrates; sp-PEPC and sp-PEPC $+\mathrm{C} 19$ are sp-PEPC fraction in the absence or presence of pC19; C19, pC19 alone. Values represent the mean \pm SD of three independent experiments

of PEPC and to study the interplay among the oligomerization state, metabolites, or the phosphorylation state of the enzyme in its proteolysis. 


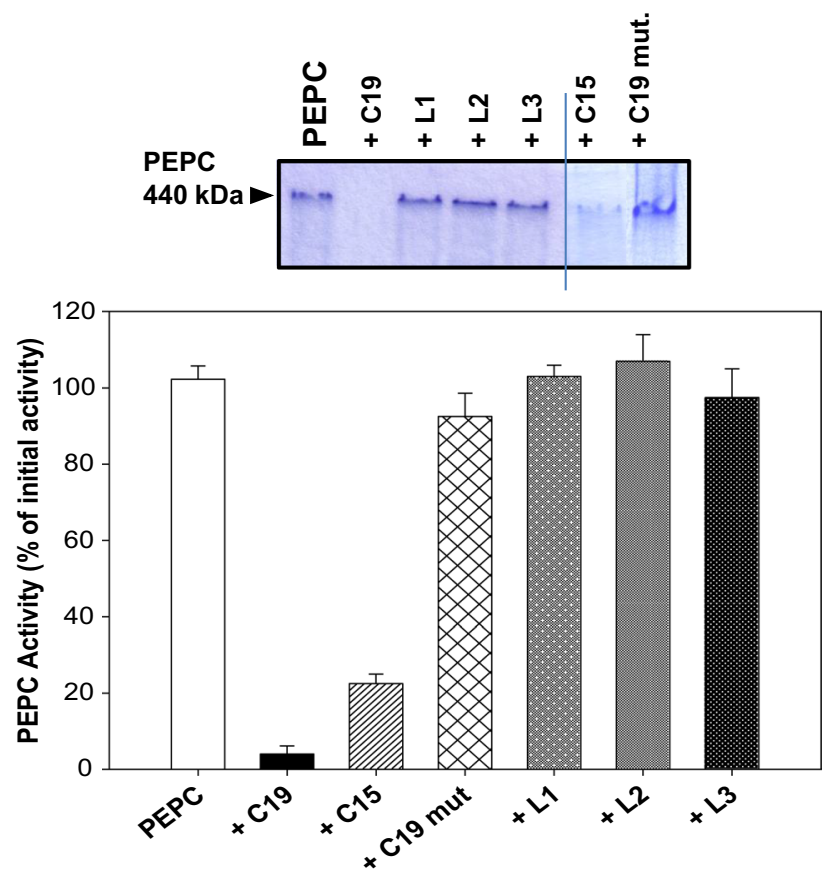

Fig. 4 Specificity of pC19 promoting PEPC proteolysis. Experiments were performed as described in the legend of Fig. 1 using $60 \mathrm{nmol}$ for peptides L1, L2, L3, pC19 (+C19), pC15 (+C15) or pC19-mut (+ C19 mut). After $3 \mathrm{~h}$ of incubation at $30^{\circ} \mathrm{C}$, PEPC activity was measured at $\mathrm{pH} 8$ and $2.5 \mathrm{mM}$ of PEP. The activity was expressed as the percentage of the initial activity (graphic). At the end of the incubation time aliquots (0.15 U PEPC) from the different samples were analyzed by native PAGE (7\% acrylamide). Protein in gel was stained with Coomassie Blue. Values represent the mean \pm SD of three independent experiments. Peptides are described in Materials and methods

\section{Monomeric and dimeric PEPC are more sensitive to proteolysis}

Aging the sp-PEPC fraction $\left(2-3\right.$ months at $\left.-20{ }^{\circ} \mathrm{C}\right)$ led to increased amounts of dimeric and monomeric enzyme species (Fig. 5a, lane 1 vs. lane 2). This was easily detected because PEPC was the dominant protein in the sp-PEPC preparation (lane 2). In the case of aging PEPC, proteolysis in the presence of pC19 was strongly enhanced compared to the freshly prepared enzyme (Fig. 5b, graphic). This suggests that the tetrameric form is the most stable conformation in the presence of the cathepsin proteases described to be present in sp-PEPC (Gandullo et al. 2019).

\section{Gluc-6P prevents the proteolysis of PEPC}

We then determined whether regulatory metabolites of PEPC affect the proteolysis of the enzyme in the presence of pC19. It is interesting that the loss of PEPC activity in the presence of $\mathrm{pC} 19$ was prevented by the allosteric activator Glc-6P (Fig. 5b, graphic). Glc-6P positively regulates

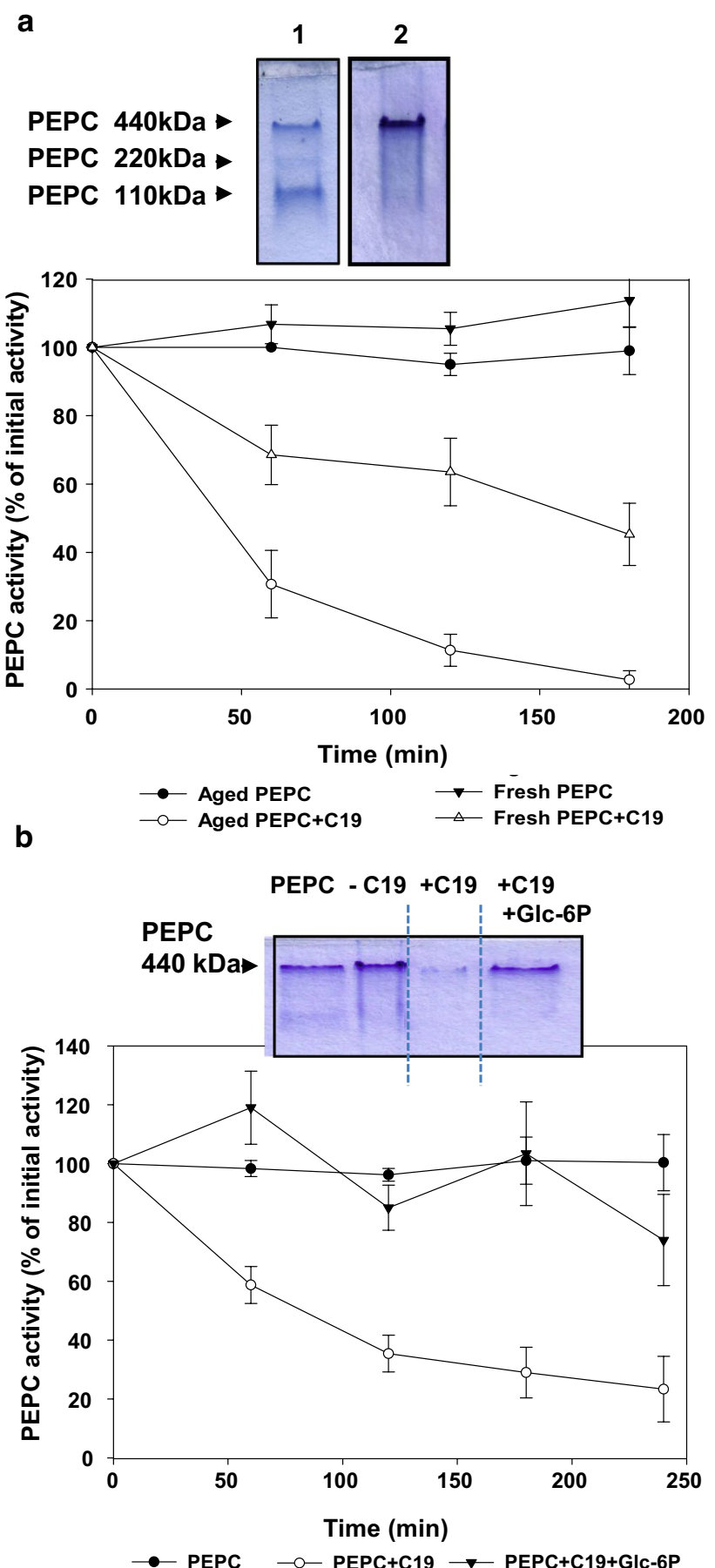

Fig. 5 The oligomerization state of PEPC and Glc-6P affect the sensitivity to proteolysis in the presence of $\mathrm{pC} 19$. a Coomassie stained PEPC in native PAGE ( $7 \%$ acrylamide). Lane 1 corresponds to a preparation of 2 month old of sp-PEPC conserved at $-20{ }^{\circ} \mathrm{C}$ (aging PEPC) and lane 2 contains freshly prepared sp-PEPC. Both lanes were loaded with $6 \mu \mathrm{g}$ protein. The graphic represents a time course of PEPC activity in the incubation assay in the absence or presence of pC19 (+ C19). 100\% corresponds to $0.3 \mathrm{U}$ PEPC and data are means of three independent experiments. b PEPC amount and activity after incubation with $\mathrm{pC} 19(+\mathrm{C} 19)$, or $\mathrm{pC} 19$ and $5 \mathrm{mM} \mathrm{Glc}-6 \mathrm{P}$ $(+\mathrm{C} 19+$ Glc-6P). A similar time course as described above was done and samples (0.15 U PEPC) were analyzed by native PAGE. Values represent the mean \pm SD of 3 independent experiments) 
PEPC by increasing its activity and preventing the subunit dissociation of the enzyme (Chollet et al. 1996). Recently, we demonstrated that Glc-6P not only prevents the exposure of the C-term of the native PEPC but returns the exposed sequence to the embedded native conformation (Gandullo et al. 2019). This indicates that Glc-6P is not only a positive effector of the enzyme's activity as largely described in the literature (Chollet et al. 1996) but also a protector of its integrity.

\section{Phosphorylated PEPC is less sensitive to proteolysis}

In $\mathrm{C}_{4}$ plants, $\mathrm{C}_{4}$-PEPC is subjected to diel post-translational regulation that alters its functional and regulatory properties (Chollet 1996; Echevarría and Vidal 2003). This occurs when a small molecular mass (32 kDa) phosphoenolpyruvate carboxylase kinase (PEPCk) phosphorylates the Ser of the enzyme's N-terminal domain (E/DR/KxxSIDAQL/ MR; Jiao et al. 1991). When performed at suboptimal $\mathrm{pH}$ (7.3) and 2.5 mM PEP, it has been established that the $\mathrm{IC}_{50}$ for L-malate (the concentration of L-malate that inhibits PEPC activity by $50 \%$ ) reflects the phosphorylated state of PEPC. Values around 1.2 and $0.4 \mathrm{mM} \mathrm{IC}_{50}$ represent phosphorylated and dephosphorylated enzymes, respectively (McNaughton et al. 1989; Echevarría et al. 1990, 1994). Taking advantage of $\mathrm{pC} 19$ to promote the proteolysis of PEPC, we explored how the phosphorylation state of the enzyme impacts on the sensitivity of the protein to proteolysis. This was done with crude extracts from illuminated (phosphorylated PEPC) or darkened (dephosphorylated PEPC) sorghum leaves. Furthermore, we phosphorylated PEPC in semi-purified fraction in vitro using the catalytic subunit of protein kinase (PKA) (an efficient PEPCk, although one thus far not found in plants; Terada et al. 1990). Previously to the addition of $\mathrm{pC} 19$, the phosphorylation state of PEPC was confirmed by L-malate test $\left(\mathrm{IC}_{50}\right)\left(\mathrm{IC}_{50}\right.$ values shown in Fig. 6a, b). As shown in Fig. 6, the phosphorylated PEPC was less sensitive to proteolysis than the dephosphorylated form. This was demonstrated by the loss of PEPC activity in the presence of pC19 and by the amount of dephosphorylated and phosphorylated sp-PEPC in PAGE after incubation in the presence of pC19 (Fig. 6c).

Proteolysis of the $\mathrm{N}$-terminal end during the purification of PEPC has been extensively reported (McNaughton et al. 1989; Baur et al. 1992; Crowley et al. 2005). In addition, $\mathrm{C}_{3}$-PEPC ( $\mathrm{RcPPC} 3$ ) from castor oil seeds exists in vivo as a proteolyzed N-terminal subunit (Uhrig et al. 2008; O'Leary et al. 2011). Similarly, we recently demonstrated that the loss of the N-terminal end of PEPC is an early event in proteolysis conducted by cathepsin proteases present in sp-PEPC in the presence of PA (Gandullo et al. 2019). Here we show that the proteolysis of PEPC was blocked in the presence of $\mathrm{N}$-t-IgGs antibodies (produced against the $\mathrm{N}$-t-peptide) in
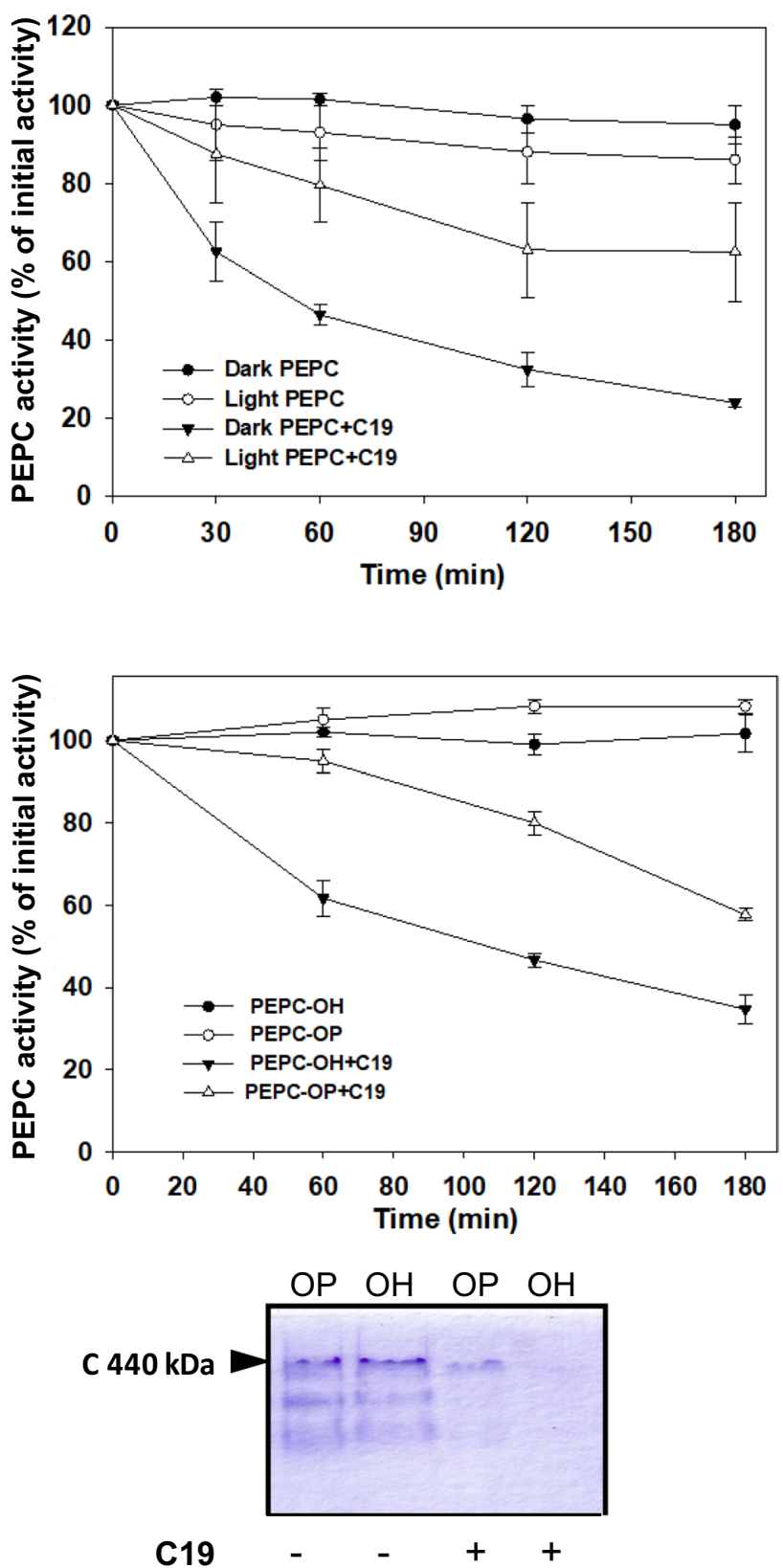

Fig. 6 Phosphorylated PEPC is less sensitive to proteolysis than dephosphorylated PEPC. a PEPC protease activity was followed during $4 \mathrm{~h}$, at $30^{\circ} \mathrm{C}$, in crude extract from illuminated (Ligh PEPC) or darkened (Dark PEPC) sorghum leaves containing 0.3 U PEPC and in the absence or presence of $60 \mathrm{nmol}$ of the $\mathrm{pC} 19(+\mathrm{C} 19)$. At the indicated time, PEPC activity was determined at $\mathrm{pH} 8$ and $2.5 \mathrm{mM}$ of PEP. $\mathbf{b}$ The same as in a but using sp-PEPC fraction previously phosphorylated or not with the catalytic subunit of the cAMP-dependent protein kinase (PKA). $\mathbf{c}$ The same as that in $\mathbf{b}$ but the analysis of the protein was performed by native PAGE ( $7 \%$ acrylamide). The $\mathrm{IC}_{50}$ values for L-malate of PEPC in crude extracts or in vitro phosphorylated PEPC are shown in the graphics $\mathbf{a}$ and $\mathbf{b}$, respectively, and was determined at $\mathrm{pH} 7.3$ and $2.5 \mathrm{mM}$ of PEP. Values represent the mean \pm SD of 3 independent experiments 
the proteolytic assay (Fig. 7, lane 7 vs. lane 2). In addition, PEPC proteolysis in the presence of $\mathrm{pC} 19$ was inhibited by the phosphorylated N-terminal peptide (N-t-OP; Fig. 7a, lane 4). However, this effect was much more pronounced when a $\mathrm{N}$-terminal dephosphorylated peptide $(\mathrm{N}-\mathrm{t}-\mathrm{OH})$ was used (Fig. 7a, lane 6), which suggests that $\mathrm{N}-\mathrm{t}-\mathrm{OH}$ is a better inhibitor of the proteases in this sp-PEPC reaction than $\mathrm{N}-\mathrm{t}-\mathrm{OP}$

Collectively, these results establish that phosphorylated PEPC is less suitable for degradation by cathepsin proteases present in sp-PEPC than the dephosphorylated enzyme. This

a

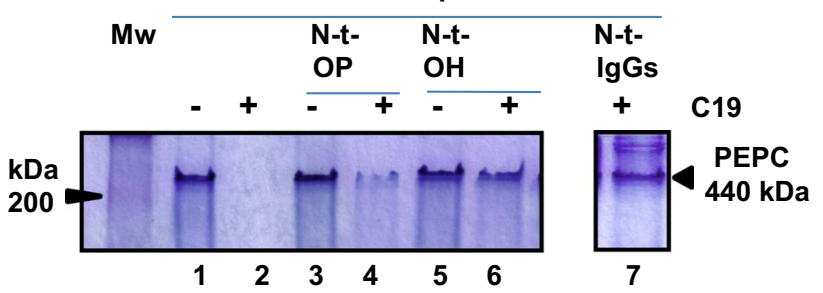

b

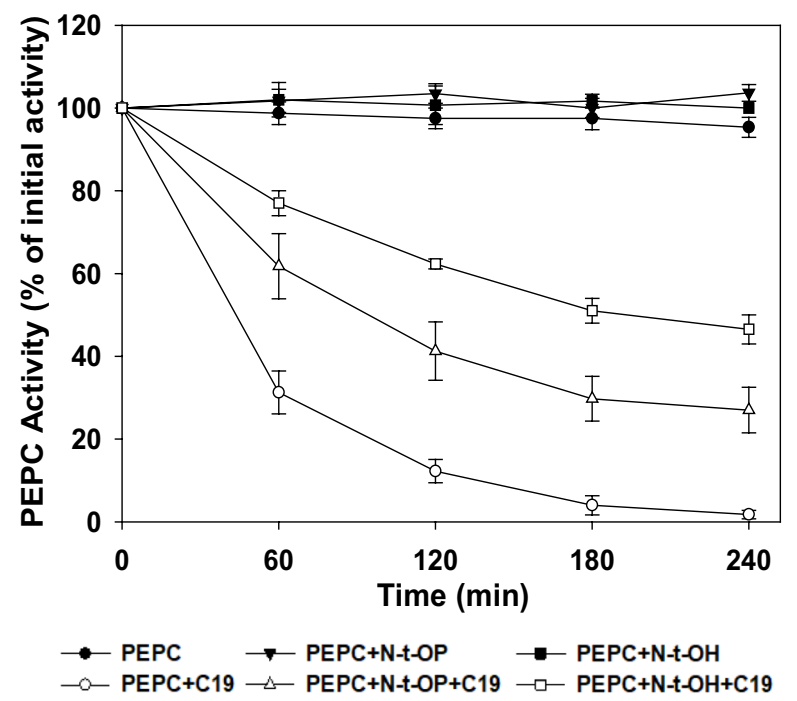

Fig. $7 \mathrm{~N}$-terminal-(N-t) dephospho-peptide $(\mathrm{N}-\mathrm{t}-\mathrm{OH})$ is a better inhibitor of PEPC proteolysis in the presence of pC19 than the N-tphospho-peptide (N-t-OP). a The N-t-peptides (N-t peptide; $60 \mathrm{nmol}$ ) were added (lanes, 3, 4, 5 and 6) or not (lanes 1, 2 and 7) to the proteolytic assay with sp-PEPC (0.3 Unit), in the presence (lanes 2, 4, 6 and 7) or absence (lanes 1, 3, 5) of $60 \mathrm{nmol}$ of pC19 (+C19). Lanes 3 and 4, phosphopeptide (N-t-OP); lanes 5 and 6 dephospho-peptide $(\mathrm{N}-\mathrm{t}-\mathrm{OH})$. Lane 7 is similar to lane 2 but in the presence of specific antibodies against peptide $\mathrm{N}-\mathrm{t}-\mathrm{OH}$ (N-t-IgGs). After $3 \mathrm{~h}$ incubation at $30{ }^{\circ} \mathrm{C}$ samples were analyzed by native PAGE (7\% acrylamide). Proteins were stained with Coomassie blue. MW, molecular weight. b Time course of PEPC activity in the presence or absence of $\mathrm{N}-\mathrm{t}$ peptide and $\mathrm{pC} 19(+\mathrm{C} 19)$. The proteolytic assay was performed in standard condition in the presence of $60 \mathrm{nmol}$ of each peptides (N-t$\mathrm{OH})$ or $(\mathrm{N}-\mathrm{t}-\mathrm{OP})$. $100 \%$ activity corresponds to $0.3 \mathrm{U}$ PEPC. Values represent the mean $\pm \mathrm{SD}$ of three independent experiments is the first report to show that the regulatory phosphorylation of $\mathrm{C}_{4}$-PEPC is a mechanism for preserving the integrity of the enzyme.

\section{Discussion}

The C-term of PEPC is a highly conserved sequence whose last 19 amino acids are present in all plant-type PEPCs (PTPCs) sequenced to date. It has been described as a hydrophobic alpha-helix sequence embedded in the subunit (Kai et al. 2003) in the active and stable conformation of the enzyme (Álvarez et al. 2003; Kay et al. 2003; Gandullo et al. 2019). The crystalline structure of maize PEPC shows that this sequence oscillates between the active (R) and nonactive (T) state of the protein. The R state is stabilized via interaction with the terminal glycine of the $\mathrm{C}$-term, which suggests the importance of the C-term in both catalytic activity and allosteric regulation (Izui et al. 2004). Along the same lines, using specific C-term IgGs (pC19-IgGs) and immunoprecipitation assay, we have demonstrated that the C-term of PEPC can be in two conformational states in vitro, embedded or exposed, being the embedded conformation the most abundant (Álvarez et al. 2003) and active conformation of the enzyme (Gandullo et al. 2019). This was investigated further to show that in vitro PA and anionic phospholipids trigger the exposed $\mathrm{C}$-term conformation, this change being correlated to its proteolysis by cathepsin proteases of the leaf extract (Monreal et al. 2010; Gandullo et al. 2019). The C-term has been also described as an important requirement for the stability of the enzyme since a mutated PEPC lacking this sequence is degraded in E. coli (Dong et al. 1999). Therefore, it was tempting to examine whether the C-term is a major player in the largely unknown mechanism of PEPC proteolysis/stability. As the C-term is normally embedded in the subunit, $\mathrm{pC} 19$ represents an efficient tool to study this possible interaction. Very unexpectedly, we found that when pC19 was added to sp-PEPC from darkened sorghum leaves, PEPC activity was rapidly lost. This was due to proteolytic degradation of the enzyme by cathepsin proteases present in the sp-PEPC fraction. In addition, in the absence of these proteases, the activity and integrity of the enzyme were not affected (Fig. 2, lane 4). The last four amino acids QNTG at the end of the $\mathrm{pC} 19$ sequence are not a necessary requirement for interaction between PEPC and $\mathrm{pC} 19$, as a $\mathrm{pC} 15$ peptide lacking these four amino acids was equally effective as pC19 at promoting the proteolysis of the enzyme (Fig. 4). However, the Thr944 and Thr948 residues are important requirements, as pC19 in which these Thr had been changed by Tyr showed a complete loss of efficiency. The interaction between pC19 and PEPC seems to be specific, as other peptides containing sequences of PEPC (L1, L2, and L3) were ineffective promoting the proteolysis (Fig. 4). Thus, one 
main requirement for $\mathrm{pC} 19$ to be active is hydrophobicity, but specificity of the amino acid sequence is also required.

It is thus reasonable to assume that $\mathrm{pC} 19, \mathrm{PEPC}$ fragment in which a C-term peptide could be found or the exposed $\mathrm{C}$-term of a PEPC subunit could interact in vivo with other native PEPC to promote the exposure of new cleavage sites and to increase its sensitivity to proteolysis. In a previous study, we reported novel results supporting the viability of this hypothesis (Gandullo et al. 2019). For example, PA increases in response to different stresses (Munnik 2001), including salinity in sorghum plants (Monreal et al. 2013). $\mathrm{PA}$ and other anionic phospholipids change $\mathrm{C}_{4}$-PEPC to a $\mathrm{C}$-term-exposed conformation, which greatly increases the susceptibility of the enzyme to proteolyzation (Gandullo et al. 2019). In contrast, Glc-6P maintains the enzyme in a conformation with an unexposed C-term (Gandullo et al. 2019) and preserves the stability of the enzyme (Fig. 5b). These data demonstrate that there are, in vivo, potential regulators of the exposition of the C-term of PEPC making possible to increase or decrease the sensitivity of the enzyme to proteolysis, and PEPC fragments with the C-term may to contribute to the autocatalysis of the processes. However, in this work we used a high ratio of $\mathrm{pC} 19$ to the PEPC protein, which suggests that the in vivo conditions in which this interaction can take place (oligomeric state of the enzyme, the real size of the peptides, or the presence of metabolites) may be essential for the interaction.

We also studied how the conformation of PEPC, regulatory metabolites, or the phosphorylation of PEPC affect the stability of the enzyme. The results presented here show that proteolysis in the presence of $\mathrm{pC} 19$ can be modulated by the oligomeric state of PEPC, with the tetrameric form the most stable (Fig. 5a). These results are in good agreement with a report by Weding and Black (1987) showing that the sensitivity of a CAM (Crassulacean acid metabolism) PEPC to proteases was clearly related to its oligomeric state. In addition, we have proven here that Glc-6P decreases the degradation of PEPC in the presence of pC19 (Fig. 5b). As described previously by our group, Glc-6P prevents the exposure of the $\mathrm{C}$-term and returns the exposed C-term conformation to the embedded state (Gandullo et al. 2019). This result suggests that an exposed or embedded C-term is key to regulating the susceptibility of the enzyme to proteolysis and describes a new role for Glc-6P not only as a positive effector (Ghollet et al. 1996) but also as a stabilizer of the integrity of the enzyme (Gandullo et al. 2019; and Fig. 5b in this work).

To date, the role assigned to the reversible phosphorylation of PEPC is to affect the catalytic and regulatory properties of the enzyme (Duff et al. 1995; Nimmo 2003). However, although this has been largely demonstrated, the lack of PEPC kinases (PEPCks) in a Flaveria bidentis mutant had no effect on photosynthetic rates (Furumoto et al. 2007). Additionally, it is difficult to explain why a modified form of $\mathrm{C}_{4}$ - or CAM-PEPC whose $\mathrm{N}$-terminal region is truncated by proteolysis shows marked desensitization to Asp or L-malate (Chollet et al. 1996; Izui et al. 2003). Furthermore, $\mathrm{a} \mathrm{C}_{3}$-PEPC from castor oil seed (RcPPC3) exists in vivo as a proteolyzed N-terminal subunit (Uhrig et al. 2008; O'Leary et al. 2011). This calls into question the unique role assigned to date to the phosphorylation of $\mathrm{C}_{4}$ - $\mathrm{PEPC}$ in $\mathrm{C}_{4}$ photosynthesis and prompted us to look for alternative functions (e.g., regulation of the stability of the enzyme). Results of this work using $\mathrm{pC} 19$ prove that phosphorylation of PEPC decreases the susceptibility of the enzyme to proteolysis.

In vivo phosphorylated PEPC from illuminated leaves showed a slowed kinetic degradation in the presence of pC19 compared to the dephosphorylated enzyme. Moreover, in vitro phosphorylated PEPC was less susceptible to degradation than the dephosphorylated form (Fig. 6). It is interesting that the addition of $\mathrm{N}-\mathrm{t}-\mathrm{IgGs}$ raised against the $\mathrm{N}$-terminus of sorghum $\mathrm{C}_{4}$-PEPC efficiently decreased the proteolysis of the enzyme (Fig. 7a, lane 7). Saturation of dephospho-PEPC with specific N-t-IgGs antibodies promotes a marked alteration of $\mathrm{C}_{4}$-PEPC functional and regulatory properties mimicking a phosphorylated enzyme (Pacquit et al. 1995). These antibodies may also block access to some essential cleavage sites and hinder proteolysis. It is curious that the addition of dephospho- or phospho-N-terminal peptides decreased the proteolysis of PEPC in the presence of pC19. However, Fig. 7 indicates that the dephosphorylated peptide was a better inhibitor of PEPC proteolysis than the phosphorylated peptide. Collectively, these results describe a new role for the reversible phosphorylation of PEPC. PEPC phosphorylation affects not only the regulatory and catalytic properties of PEPC (Echevarría et al. 1994) but also the stability of the enzyme. In line with these results, $\mathrm{C}_{4}$-PEPC from salt-treated sorghum plants was highly phosphorylated (Echevarría et al. 2001), and the enzyme was much more stable against degradation than those in control conditions (García-Mauriño et al. 2003; Monreal et al. 2007). Conversely, phosphorylation of PEPC from guard cells of Vicia faba, a $\mathrm{C}_{3}$-PEPC isoenzyme, participates in the enzyme's degradation (Klockenbring et al. 1998).

In this work, we demonstrate that dephosphorylated PEPC is a better substrate than phosphorylated PEPC for the cathepsin proteases present in sp-PEPC. All together, these data allow us to suggest a model in which the $\mathrm{C}$-term of PEPC may be exposed or embedded; molecules in the first group would not be phosphorylated (PEPCk would be inhibited by the exposed C-term; Álvarez et al. 2003) and would ideally be sent for proteolysis, whereas those in the second group would be phosphorylated, thus increasing the stability of the enzyme. In this model, Glc-6P and PA trigger each conformation, with Glc-6P acting as a protector and PA acting as an inducer of enzyme degradation. It is interesting that the presence of Glc-6P and PEPC phosphorylation are 
related to the active phase of $\mathrm{CO}_{2}$ fixation in $\mathrm{C}_{4}$ photosynthesis (Nimmo et al. 2003), whereas increased PA in the cell is related to stress processes (Testerink and Munnik 2005).

\section{Author contribution statement}

CE conceived the research hypothesis. CE, JG, RA, and JV designed the study and conducted the research. ABF and JAM co-supervised the research. ID provided fluorescent substrates of proteases and cystatin for the protease characterization experiments, which were performed in her laboratory by JG. CE wrote the manuscript.

Supplementary Information The online version contains supplementary material available at https://doi.org/10.1007/s00425-021-03692-3.

Acknowledgements We thank Sofía García-Mauriño for her participation in scientific discussion. We also thank technical services of the Centro de Investigación, tecnología e innovación of the University of Seville.

Funding Open Access funding provided thanks to the CRUE-CSIC agreement with Springer Nature. This research was supported by the Spanish Ministerio de Ciencia e Innovación (Grant numbers BFU200761431-BMC, AGL2012-35708, and AGL2016-75413-P), by the Junta de Andalucía (Grant numbers P06-CVI-02186 and P12-FQM-489), and by the Grupo de Investigación de Fosforilación de Proteínas en Plantas y Metabolismo del Carbono BIO-298 from the Junta de Andalucía.

Data availability All data generated or analyzed during this study are included in this published article.

Open Access This article is licensed under a Creative Commons Attribution 4.0 International License, which permits use, sharing, adaptation, distribution and reproduction in any medium or format, as long as you give appropriate credit to the original author(s) and the source, provide a link to the Creative Commons licence, and indicate if changes were made. The images or other third party material in this article are included in the article's Creative Commons licence, unless indicated otherwise in a credit line to the material. If material is not included in the article's Creative Commons licence and your intended use is not permitted by statutory regulation or exceeds the permitted use, you will need to obtain permission directly from the copyright holder. To view a copy of this licence, visit http://creativecommons.org/licenses/by/4.0/.

\section{References}

Álvarez R, García-Mauriño S, Feria AB, Vidal J, Echevarría C (2003) A conserved 19 amino acids synthetic peptide from the carboxy terminus of phosphoenolpyruvate carboxylase inhibits the in vitro phosphorylation of the enzyme by the calcium-independent phosphoenolpyruvate carboxylase kinase. Plant Physiol 132:1097-1106

Arias-Baldrich C, de la Osa C, Bosch N, Ruiz-Ballesta I, Monreal JA, García-Mauriño S (2017) Enzymatic activity, gene expression and posttranslational modifications of photosynthetic and non-photosynthetic phosphoenolpyruvate carboxylase in ammonium-stressed sorghum plants. J Plant Physiol 214:39-47

Baena G, Feria AB, Echevarría C, Monreal JA, García-Mauriño S (2017) Salinity promotes opposite patterns of carbonylation and nytrosilation of $\mathrm{C}_{4}$ phosphoenolpyruvate carboxylase in sorghum leaves. Planta 246:1203-1214. https://doi.org/10.1007/ s00425-017-2764-y

Baena G, Feria AB, Hernández-Huertas L, Gandullo J, Echevarría C, Monreal JA, García-Mauriño S (2021) Genetic and pharmacological inhibition of autophagy increases the monoubiquitination of non-photosynthetic phosphoenolpyruvate carboxylase. Plants 10:12. https://doi.org/10.3390/plants10010012

Baur B, Dietz KJ, Winter K (1992) Regulatory protein phosphorylation of phosphoenolpyruvate carboxylase in the facultative crassulacean-acid-metabolism plant Mesembryanthemun crystallinum L. Eur J Biochem 209(1):95-101

Bradford MM (1976) A rapid and sensitive method for the quantitation of microgram quantities of protein utilizing the principle of protein-dye binding. Anal Biochem 72:248-254

Carrillo L, Martínez M, Ramessar K, Cambra I, Castañeda P, Ortego P, Díaz I (2011) Expression of barley cystatine gene in maize enhances resistance against phytophagous mites by altering their cystein proteases. Plant Cell Rep 30:101-112

Chollet R, Vidal J, O'Leary MH (1996) Phosphoenolpyruvate carboxylase: a ubiquitous, highly regulated enzyme in plants. Annu Rev Plant Physiol Plant Mol Biol 47:273-298

Crowley V, Gennidakis K, Plaxton WC (2005) In vitro proteolysis of phosphoenolpyruvate carboxylase from developing castor oil seeds by an endogenous thiol endopeptidase. Plant Cell Physiol 46:1855-1862

Dong L, Patil S, Condon S, Hass E, Chollet R (1999) The conserved C-terminal tetrapeptide of sorghum $\mathrm{C}_{4}$ phosphoenolpyruvate carboxylase is indispensable for maximal catalític activity, but not for homotetramer formation. Arch Biochem Biophys 371:124-128

Duff SMG, Andreo CS, Pacquit V, Lepiniec L, Sarath G, Condon SA, Vidal J, Chollet GP (1995) Kinetic analysis of the non-phosphorylated, in vitro phosphorylated, and phosphorylation-site-mutant (Asp8) forms of intact recombinant $\mathrm{C}_{4}$ phosphoenolpyruvate carboxylase from sorghum leaves. Eur J Biochem 228:92-95

Echevarría C, Vidal J (2003) The unique phosphoenolpyruvate carboxylase kinase. Plant Physiol Biochem 41:541-547

Echevarría C, Vidal J, Jiao JA, Chollet R (1990) Reversible light activation of the phosphoenolpyruvate carboxylase protein-serine kinase in maize leaves. FEBS Lett 275:25-28

Echevarría C, Pacquit V, Bakrim N, Osuna L, Delgado B, ArrioDupont M, Vidal J (1994) The effect of $\mathrm{pH}$ on the covalent and metabolic control of $\mathrm{C}_{4}$ phosphoenolpyruvate carboxylase from sorghum leaf. Arch Biochem Biophysics 313:425-430

Echevarría C, García-Mauriño S, Álvarez R, Soler A, Vidal J (2001) Salt stress increases the $\mathrm{Ca}^{2+}$ - independent phosphoenolpyruvate carboxylase kinase activity in sorghum leaves. Planta 214:283-287

Furumoto T, Izui K, Quinn V, Furbank RT, Von Caemmerer S (2007) Phosphorylation of phosphoenolpyruvate carboxylase is not essential for high photosynthetic rates in the $\mathrm{C} 4$ species Flaveria bidentis. Plant Physiol 144:1936-1945

Gandullo J, Monreal JA, Álvarez R, Díaz I, García-Mauriño S, Echevarría C (2019) Anionic phospholipids induce conformational changes in phosphoenolpyruvate carboxylase to increase sensitivity to cathepsin proteases. Front Plant Sci 10:82-93. https:// doi.org/10.3389/fpls.2019.00582

García-Mauriño S, Monreal JA, Álvarez R, Vidal J, Echevarría C (2003) Characterization of salt stress-enhanced phosphoenolpyruvate carboxylase kinase activity in leaves of Sorghum vulgare: 
independence from osmotic stress, involvement of ion toxicity and significance of dark phosphorylation. Planta 216:648-655

Gehrig HH, Valentina H, Kluge M (1998) Towards a better knowledge of the molecular evolution of phosphoenolpyruvate carboxylase by comparison of partial cDNA sequences. J Mol Evol 46:107-114

Grisvard J, Keryer E, Takvorian A, Dever LV, Lea PJ, Vidal J (1998) A splice site mutation gives rise to a mutant of the $\mathrm{C}_{4}$ plant Amaranthus edulis deficient in phosphoenolpyruvate carboxylase activity. Gene 213:31-33

Hewitt EJ (1966) The composition of the micronutrient solution. In: sand and water culture methods in the study of plants nutrition. Commonwealth Agricultural Bureaux of Hort Tech, Commum $\mathrm{N}^{\circ} 22$

Izui K, Tsuchida Y, Agetsuma M, Ohshima K, Furumoto T (2003) Enzymatic characterization of the recombinant phosphoenolpyruvate carboxylase kinase (PEPCPK) from a C4 plant, Flaveria trinervia: Possible redox regulation. Presented at Annu Meet Am Soc Plant Biol Honolulu 55:69-84

Izui K, Matsumura H, Furumoto T, Kai Y (2004) Phosphoenolpyruvate carboxylase: a new era of structural biology. Annu Rev Plant Biol 55:69-84

Jiao JA, Vidal J, Echevarría C, Chollet R (1991) In vivo regulatory phosphorylation site in $\mathrm{C}_{4}$-leaf phosphoenolpyruvate carboxylase from maize and sorghum. Plant Physiol 96:297-323

Kai Y, Matsumura H, Inoue T, Terada K, Nagara Y, Yoshinaga T, Kihara T, Tsumura K, Izui K (1999) Tree-dimensional structure of phosphoenolpyruvate carboxylase: a proposed mechanism for allosteric inhibition. Proc Natl Acad Sci USA 96:823-828

Kai Y, Matsumura H, Izui K (2003) Phosphoenolpyruvate carboxylase: three dimensional structure and molecular mechanisms. Arch Biochem Biophys 414:170-179

Klockinbring T, Meinhard M, Schnabl H (1998) The stomatal phosphoenolpyruvate carboxylase a potential target for selective proteolysis during stomatal closure? J Plant Physiol 152:222-229

Laemmli UK (1970) Cleavage of structural proteins during the assembly of the head of bacteriophage T4. Nature 227:680-688

Lepiniec L, Keryer E, Philippe H, Gadal P, Cretin C (1993) Sorghum phosphoenolpyruvate carboxylase gene family: structure, function and molecular evolution. Plant Mol Biol 21:487-502

Martínez M, Díaz I (2008) The origin and evolution of plant cystatins and their target cysteine proteinase indicate a complex functional relationship. BMC Evol Biol 8:198. https://doi.org/10.1186/ 1471-2148-8-148

Matsumura H, Xie Y, Shirakata S, Inoue T, Yoshinaga T, Ueno Y, Izui $\mathrm{K}$, Kai Y (2002) Cristal structure of $\mathrm{C}_{4}$ form maize and quaternary complex of $E$. coli phosphoenolpyruvate carboxylase. Structure 10:1721-1730

McNaughton GAL, Fewson CA, Wilkins MB, Nimmo HG (1989) Purification, oligomerization state and malate sensitivity of maize leaf phosphoenolpyruvate carboxylase. Biochem J 261:349-355

McNaughton GA, Fewson CA, Wilkins MB, Nimmo HG (1989) Purification, oligomerization state and malate sensitivity of maize leaf phosphoenolpyruvate carbaxylase. Biochem J 261:349-355

Monreal JA, Feria AB, Vinardell JM, Vidal J, Echevarría C, GarcíaMauriño S (2007) ABA modulates the degradation of phosphoenolpyruvate carboxylase kinase in sorghum leaves. FEBS Lett 581:3468-3472

Monreal JA, McLoughlin F, Echevarría C, García-Mauriño S, Testerink C (2010) Phosphoenolpyruvate carboxylase from $\mathrm{C}_{4}$ leaves is selectively targeted for inhibition by anionic phospholipids. Plant Physiol 152:634-638

Monreal JA, Arias-Baldrich C, Pérez-Montaño F, Gandullo J, Echevarría C, García-Mauriño S (2013) Factors involved in the rise of phosphoenolpyruvate carboxylase-kinase activity caused by salinity in sorghum leaves. Planta 237:1401-1413

Munnik T (2001) Phosphatidic acid: an emerging plant lipid second messenger. Trends Plant Sci 6:227-233

Nimmo HG (2003) Control of phosphorylation of phosphoenolpyruvate carboxylase in higher plants. Arch Biochem Biophys 414:189-196

O'Leary B, Park J, Plaxton WC (2011) The remarkable diversity of plant PEPC (phosphoenolpyruvate carboxylase): recent insights into the physiological function and post-translational controls of non-photosynthetic PEPC. Biochem J 436:15-34

Pacquit V, Giglioli N, Crétin C, Pierre JN, Vidal J, Echevarría C (1995) Regulatory phosphorylation of $\mathrm{C} 4$ phosphoenolpyruvate carboxylase from Sorghum: An immunological study using specific antiphosphorylation site antibodies. Photosynth Res 43:283-288

Paterson AH, Bowers JE, Bruggmann R et al (2009) The Sorghum bicolor genome and the diversification of grasses. Nature 457:551-556

Plaxton WC (2019) Avoiding proteolysis during the extraction and purification of active plant enzymes. Plant Cell Phys 60:715-724

Ruíz-Ballesta I, Feria AB, Ni H, She YM, Plaxton WC, Echevarría $C$ (2014) In vivo monoubiquitination of anaplerotic phosphoenolpyruvate carboxylase occurs at Lys624 in germinating sorghum sedes. J Exp Bot 65(2):443-451

Ruíz-Ballesta I, Baena G, Gandullo J, Wang L, She YM, Plaxton WC, Echevarría C (2016) New insights into the post-translational modification of multiple phosphoenolpyruvate carboxylase isoenzymes by phosphorylation and monoubiquitination during sorghum seed development and germination. J Exp Bot 67(2):3523-3526

Sabe H, Miwa T, Kodaki T, Izui K, Hiraga S, Katsuki H (1984) Molecular cloning of the phosphoenolpyruvate carboxylase gene, $p p c$, of Escherichia coli. Gene 31:279-283

Sánchez R, Cejudo FJ (2003) Identification and expression analysis of a gene encoding a bacterial-type phosphoenolpyruvate carboxylase from Arabidopsis and rice. Plant Physiol 132:949-957

Terada K, Kai T, Okuno S, Fujisawa H, Izui K (1990) Maize leaf phosphoenolpyruvate carboxylase: phosphorylation of $\operatorname{Ser}^{15}$ with mammalian cyclic AMP-dependent protein kinase diminishes sensitivity to inhibition by malate. FEBS Lett 259:241-244

Testerink C, Munnik T (2005) Phosphatidic acid: a multifunctional stress signaling lipid in plants. Trends Plant Sci 10(8):368-375. https://doi.org/10.1016/j.tplants.2005.06.002

Uhrig RG, She YM, Leach CA, Plaxton WC (2008) Regulatory monoubiquitination of phosphoenolpyruvate carboxylase in germinating castor oil seeds. J Biol Chem 283:29650-29657

Wedding RT, Black MK (1987) Oligomerization and the sensitivity of phosphoenolpyruvate carboxylase to inactivation by proteinases. Plant Physiol 84:979-981

Yamada TY, Ohta H, Shinohara A, Iwamatsu A, Shimada H, Tsuchiya T, Masuda T, Takamiya K (2000) A cysteine protease from maize isolated in a complex with cystatin. Plant Cell Physiol 41:185-191

Publisher's Note Springer Nature remains neutral with regard to jurisdictional claims in published maps and institutional affiliations. 